DOI 10.15290/cnisk.2018.01.05.07

MGR AGNIESZKA DROZDOWSKA

orcid.org/0000-0003-2713-7958

Uniwersytet w Białymstoku

\title{
Liga Kobiet w województwie białostockim - stan badań i postulaty badawcze ${ }^{1}$
}

\section{Streszczenie}

Liga Kobiet była najbardziej masowa organizacja kobieca w Polsce Ludowej. Mimo przemian, jakie zachodziły w działalności organizacji, zawsze realizowała wytyczne władzy komunistycznej. Organizacja zrzeszajacca nawet dwa miliony kobiet, nie została dotąd dostatecznie opracowana. Dużą uwage w przyszłych badaniach naukowych należy poświęcić działalności Ligi Kobiet w terenie, tzn. na szczeblach wojewódzkich, powiatowych czy miejskich. Poniższy artykuł prezentuje stan badań na temat Ligi Kobiet województwa białostockiego w świetle innych województw oraz kierunki i postulaty badawcze przyszłych dociekań naukowych.

Słowa kluczowe: Społeczno-Obywatelska Liga Kobiet, Liga Kobiet, Liga Kobiet Polskich, organizacja kobieca, województwo białostockie, Polska Ludowa

1 Artykuł przygotowany w ramach realizacji projektu badawczego Narodowego Centrum Nauki pt. Liga Kobiet $w$ terenie. Działalność organizacji i realia jej funkcjonowania na szczeblu regionalnym i lokalnym $w$ rzeczywistości Polski Ludowej (1945-1989), nr 2017/25/B/HS3/02015. 


\title{
LEAGUE OF WOMEN IN THE BIALYSTOK VOIVODSHIP - RESEARCH STATUS AND RESEARCH POSTULATES
}

\begin{abstract}
The League of Women was the most mass women's organization in People's Republic of Poland. Despite the changes that took place in the activities of the organization, it always implemented the guidelines of the communist authorities. The organization associating up to two million women was not sufficiently researched on yet. A lot of attention in future scientific research should be devoted to the activities of the League of Women in the field, i.e. at the voivodship, poviat or city level. The article presents the state of research on the League of Womenof the Bialystok voivodshipin the light of other voivodships, as well as the directions and research postulates of future scientific inquiries.

Keywords: Social-Civic League of Women, Leagueof Women, Polish Women's League, women's organization, Białystok Province, People's Republic of Poland

Dzieje kobiet okresu Polski Ludowej były poruszane w badaniach naukowych w niewielkim zakresie. Wybrane wątki i okresy nie wyczerpują zagadnienia, a jedynie stanowia przyczynek do dalszych badań w tym zakresie $^{2}$. Działalność najbardziej masowej organizacji kobiecej w PRL również nie została dostatecznie opracowana. W polskiej historiografii nie ukazała się dotąd żadna monografia w całości poświęcona Lidze Kobiet doby $\mathrm{PRL}^{3}$. Próbę całościowego przedstawienia działalności organizacji podjęła w 2004 r. Barbara Nowak. W swojej pracy doktorskiej Serving

\footnotetext{
2 K. Stańczak-Wiślicz, P. Perkowski, Dzieje kobiet $w$ PRL - stan i perspektywy badań [w:] Dzieje kobiet w Polsce. Dyskusja wokół przyszłej syntezy, red. K.A. Makowski, Poznań 2014, s. 134-156.

3 W latach 1945-1948 organizacja funkcjonowała pod nazwą Społeczno-Obywatelska Liga Kobiet. Od 1949 r. istniała jako Liga Kobiet, a od 1982 r. jako Liga Kobiet Polskich (M. Dajnowicz, „Zwierciadło” - platforma polityczna Ligi Kobiet w okresie PRL (1957-1961, 1982-1989), „Rocznik Historii Prasy Polskiej” 2017, t. 20, z. 3 (47), s. 69; A. Klepacz, Liga Kobiet Polskich ma 100 lat [online], [Dostęp: 17.10.2018]. Dostępny w World Wide Web: <https://goo.gl/cgm7LB>; A. Stasiewicz, Działalność Społeczno-Obywatelskiej Ligi Kobiet w latach 1945-1948 na Białostocczyźnie $w$ świetle dokumentów PPR [w:] Kobiety na zakręcie 1933-1989, red. E. Chabros, A. Klarman, Wrocław 2014, s. 52).
} 
women and the state: the league of women in Communist Poland 4 głowna uwage poświęciła aktywności Ligi na szczeblu krajowym. Ukazujacc organizacje jako przedstawicielkę władz państwowych, a jednocześnie potrzeb i praw kobiet, wykorzystała przede wszystkim publikacje prasowe, wywiady z członkiniami organizacji oraz nieliczne materiały archiwalne $\mathrm{e}^{5}$. Mankamentem jej pracy jest niewykorzystanie wszystkich dostępnych źródeł archiwalnych zdeponowanych m.in. w Instytucie Pamięci Narodowej oraz wojewódzkich Archiwach Państwowych ${ }^{6}$.

Uwage na dzieje kobiet w Polsce Ludowej zwróciła także Małgorzata Fidelis. Jej ksiażka Women, Communism, and Industrialization in Postwar Poland ${ }^{7}$, przetłumaczona na język polski, traktuje o kobietach pracujących w górnictwie i przemyśle tekstylnym. Porusza ważny temat emancypacji i równouprawnienia kobiet, stawia tezę, że pleć (gender) stała się podstawowa kategoria budujaca hierarchię spoleczeństwa polskiego po II wojnie światowej ${ }^{3}$. Autorka przeciwstawia się powszechnemu przekonaniu o „podwójnym obciążeniu” kobiet praca w domu i zakładzie9.

Większość powstałych opracowań koncentruje się na pierwszych latach działalności Ligi Kobiet. Ważne ustalenia o założeniach i funkcjonowaniu organizacji na szczeblu krajowym poczynił Dariusz Jarosz $\mathrm{w}$ artykule pt. Idee, programy i realia: funkcje Ligi Kobiet $w$ porzadku instytucjonalnym Polski Ludowej (1945-1957)10. Wskazał kierunki działalności i zmiany ideologiczno-programowe zachodzące w organizacji pod wpływem polityki państwa. W swoich badaniach nad historia społeczna Polski Ludowej zwrócił uwagę na sytuację kobiet w okresie realizacji założeń planu 6-letniego oraz możliwości awansu społecznego kobiet pro-

\footnotetext{
4 B. Nowak, Serving women and the state: the league of women in Communist Poland, praca dokt., Ohio State University, 2004, [Dostęp: 7.09.2018]. Dostępny w World Wide Web: <http://bitly.pl/y5yOm>.

5 D. Jarosz, Idee, programy i realia: funkcje Ligi Kobiet $w$ porzadku instytucjonalnym Polski Ludowej (1945-1957) [w:] Działaczki społeczne, feministki, obywatelki. Samoorganizowanie sie kobiet na ziemiach polskich po 1918 roku (na tle porównawczym), t. 2, red. A. Janiak-Jasińska, K. Sierakowska, A. Szwarc, Warszawa 2009, s. 307.

6 M. Dajnowicz, Działalność Społeczno-Obywatelskiej Ligi Kobiet w świetle „Naszej Pracy” (1947-1949) [w:] Polityka i politycy w prasie XX i XXI wieku, red. M. Dajnowicz, A. Miodowski, Białystok 2016, s. 295-296.

7 M. Fidelis, Kobiety, komunizm i industrializacja w powojennej Polsce, przeł. M. Jaszczurowska, Warszawa 2010, s. 111, 232, 235-240.

$8 \quad$ K. Stańczak-Wiślicz, P. Perkowski, op. cit., s. 144.

9 A. Mrozik, Wywołać z milczenia. Historia kobiet $w$ PRL-u - kobiety $w$ historii $P R L-u$, „Teksty Drugie” 2014, nr 4, s. 112-119.

10 D. Jarosz, op. cit., s. 307-330.
} 
pagowane w prasie ${ }^{11}$. Na wizerunek kobiet promowany w periodykach do zakończenia realizacji planu 6-letniego zwrócili także uwagę Małgorzata Hajdo $^{12}$ i Piotr Perkowski ${ }^{13}$.

Na marginesie badań nad sytuacją robotnic Natalia Jarska ${ }^{14}$, podobnie jak Marta Madejska ${ }^{15}$, wskazywała na działania Ligi Kobiet podejmowane w zakresie pomocy kobietom pracującym. Jarska zwróciła uwagę na aktywność Ligi Kobiet w jednej z poznańskich dzielnic (Wilda) po zakończeniu planu 6-letniego do momentu powołania zwiazków zawodowych, tj. w latach 1956-1966 ${ }^{16}$, oraz podczas obchodów Dnia Kobiet ${ }^{17}$. Jej ostatni artykuł pt. A Patriarchal Marriage? The Women's Movement And The Communist Party in Poland ${ }^{18}$ wskazuje zależności między władzą a ruchem kobiecym w Polsce Ludowej. Autorka analizuje dyskusję, czy organizacje kobiece były wyłącznie narzędziem realizacji polityki komunistycznej, czy miały swobodę działania na rzecz kobiet. Jarska podjęła próbę prezentacji relacji między PZPR a Ligą Kobiet oraz działań realizowanych zgodnie $z$ linia partii.

Dzieje najbardziej masowej organizacji kobiecej Polski Ludowej były także obiektem zainteresowania m.in. Anny Nowakowskiej-Wierzchoś $^{19}$, Sławomiry Walczewskiej ${ }^{20}$, która bardzo krytycznie oceniła działal-

\footnotetext{
11 Idem, Kwestia kobieca $w$ Polsce stalinowskiej [w:]Idem, Polacy a stalinizm 1948-1956, Warszawa 2000; idem, Wzory osobowe i modele awansu spolecznego kobiety wiejskiej $w$ Polsce $w$ prasie periodycznej z lat 1949-1955 [w:] Kobieta i edukacja na ziemiach polskich w XIX i XX wieku, red. A. Żarnowska, A. Szwarc, Warszawa 1993, s. 253-266.

12 M. Hajdo, Wizerunek kobiety jako matki, pracownika i działaczki społecznej prezentowany na łamach prasy kobiecej w latach 1948-1956, „Dzieje Najnowsze” 2006, nr 3, s. 55-72.

${ }_{13}$ P. Perkowski, Aktywność zawodowa gospodyń domowych na łamach prasy kobiecej Polski Ludowej [w:] Koniec mitu niewinności? Płeć $i$ seksualność $w$ socjalizacji $i$ edukacji, red. L. Kopciewicz, E. Zierkiewicz, Warszawa 2009, s. 289-315.

14 N. Jarska, Kobiety z marmuru. Robotnice $w$ Polsce $w$ latach 1945-1960, Warszawa 2015, s. 40, 42, 58-65, 75, 83-92, 109-111, 119-120, 156-160, 192, 196-199, 211 , 237-241, 282-288, 306.

15 M. Madejska, Aleja włókniarek, Wołowiec 2018, s. 204-205.

16 N. Jarska, Liga Kobiet w terenie. Działalność Zarzadu Dzielnicowego Poznań-Wilda w latach 1956-1966 [w:] Letnia Szkoła Historii Najnowszej 2009. Referaty, red. Ł. Kamiński, T. Kozłowski, Warszawa 2010, s. 149-158.

17 Eadem, Obchody Dnia Kobiet w Polsce Ludowej, „Dzieje Najnowsze” 2010, nr 4, s. 15-28.

18 Eadem, A Patriarchal Marriage? The Women's Movement and The Communist Party in Poland (1945-1989), „Kwartalnik Historyczny” 2018, Vol. CXXV, Eng.-Language Edition no. 2, pp. 7-37.

19 A. Nowakowska-Wierzchoś, Społeczno-Obywatelska Liga Kobiet (1945-1949) iZwiazek Kobiet Polskich im. Marii Konopnickiej we Francji (1944-1950) - dokumenty programowe, „Komunizm: System - Ludzie - Dokumentacja” 2013, nr 2, s. 253, [Dostęp: 10.10.2018]. Dostępny w World Wide Web: <http://bitly.pl/ejwnp>.

20 S. Walczewska, Liga Kobiet - jedyna organizacja kobieca w PRL, [Dostęp: 30.10.2018]. Dostępny w World Wide Web: <http://bitly.pl/amOZ3>.
} 
ność Ligi. W swoim artykule wysunęła tezę, że Liga Kobiet przyczyniła się do zwiększenia bierności politycznej kobiet $i$ ich wycofania $w$ prywatność. Próbę polemiki z tym poglądem w 2000 r. podjęła Katarzyna Jurkowska w artykule pt. Kłopoty z tożsamościa ${ }^{21}$. Jurkowska przeprowadziła wywiad z Izabela Jaruga-Nowacka, ówczesna przewodniczącą Zarządu Głównego Ligi Kobiet Polskich. Specyfikę organizacji badali również Marcin Kruszyński $^{22}$ oraz Natasza Lubik-Reczek i Rafał Reczek ${ }^{23}$. Ci ostatni, prócz nakreślenia podstaw powołania organizacji i kierunków działalności w kraju, szczególną uwagę zwrócili na aktywność Ligi Kobiet w województwie wielkopolskim. Pierwsze lata rozwoju organizacji analizowała też Urszula Ćwik, która na podstawie „Mody i Życia Praktycznego” wskazała cele Ligi upowszechniane na łamach pisma ${ }^{24}$.

W strukturach Ligi Kobiet podległe zarządowi głównemu były zarządy wojewódzkie, a tym odpowiednio zarządy powiatowe i miejskie. Działały koła blokowe, terenowe i zakładowe. Elementem składowym Ligi od 1969 r. były także Koła Rodzin Milicyjnych, które zrzeszały środowisko jedynie funkcjonariuszy Milicji Obywatelskiej oraz ich rodziny. Koła Ligi Kobiet istniały nawet w więzieniu karno-śledczym w Białymstoku ${ }^{25}$. Istotne ustalenia na temat realizacji wytycznych oraz działalności propagandowej ZGLK i funkcjonowania Kół Rodzin Milicyjnych poczyniła Anna Marcinkiewicz-Kaczmarczyk ${ }^{26}$.

${ }^{21}$ K. Jurkowska, Kłopoty z tożsamościa, czyli Liga Kobiet Polskich, „Ośka” 2000, nr 2, s. $37-38$.

${ }^{22}$ M. Kruszyński, O zaangażowaniu kobiet $w$ działalność partii komunistycznej i Ligi Kobiet na przykładzie lubelskiego UMCS z czasów stalinowskich, „Komunizm: System - Ludzie - Dokumentacja" 2013, nr 2, s. 5-26, [online], [Dostęp: 11.10.2018]. Dostępny w World Wide Web: <http://bitly.pl/TVzaC>.

${ }^{23}$ N. Lubik-Reczek, R. Reczek, Liga Kobiet-organizacja „reprezentujaca” interesy kobiet $w$ Polsce Ludowej. Zarys działania, „Środkowoeuropejskie Studia Polityczne” 2013, t. 4, s. 105-120, [online], [Dostęp: 12.10.2018]. Dostępny w World Wide Web: <http://bitly. $\mathrm{pl} / \mathrm{FWePD}>$.

${ }_{24}$ U. Ćwik, Podstawowe założenia Społeczno-Obywatelskiej Ligi Kobiet w świetle „Mody i Życia Praktycznego" (1946-1951) [w:] Polityka i politycy w prasie XX i XXI wieku. Prasa organizacji politycznych, red. M. Dajnowicz, A. Miodowski, Białystok 2017, s. 49-58.

25 M. Zwolski, Więzienie w Białymstoku w latach 1944-1956, Białystok 2011, s. 181-183;

A. Stasiewicz, op. cit., s. 60.

26 A. Marcinkiewicz-Kaczmarczyk, Rola Ligi Kobiet w popularyzowaniu polityki władz „Polski Ludowej” [w:] „Polska Ludowa” 1944-1989 - wybrane problemy historii politycznej i społecznej, red. D. Litwin-Lewandowska, K. Bałękowski, Lublin 2016, s. 285; Eadem, Treści propagandowe rozpowszechniane przez Społeczno-Obywatelska Lige Kobiet na podstawie pisma „Poznajmy Prawde” (1946-1952) [w:] Polityka i politycy w prasie XX i XXI wieku. Prasa..., s. 59-72; Eadem, Koła Rodzin Milicyjnych - powstanie, organizacja i praca propagandowa, „Czasopismo Naukowe Instytutu Studiów Kobiecych” 2017, nr 1(2), 
Społeczno-Obywatelska Liga Kobiet została powołana w Białymstoku w marcu 1946 r., struktury terenowe tworzyła już jednak od sierpnia 1945 r. ${ }^{27}$ Rozważania nad kierunkami i strukturami Ligi Kobiet w województwie białostockim prowadzili głównie badacze związani $z$ tym obszarem. Najwcześniej tematem tym zainteresowała się Izabela Ratman-Liwerska, która w pracy pt. Stowarzyszenie jako czynnik spo-

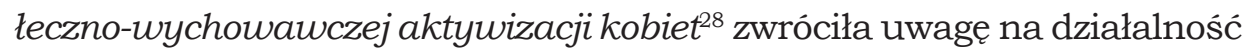
Ligi w tym zakresie. Zarysowujac historię powstania organizacji w Białymstoku, korzystała przede wszystkim $z$ materiałów archiwalnych i prasowych. Wysunęła też tezę, że początkowy okres w rozwoju organizacji o charakterze ideowo-wychowawczym budził na Białostocczyźnie opór ${ }^{29}$. Jej ustalenia na temat Ligi Kobiet niewątpliwie stanowią ważny punkt odniesienia dla przyszłych badań nad organizacja.

Badania nad Liga Kobiet w województwie białostockim prowadziła również Agnieszka Stasiewicz. Jej artykuł pt. Działalność Społeczno-Obywatelskiej Ligi Kobiet $w$ latach 1945-1948 ${ }^{30}$ koncentrował się jedynie wokół działalności politycznej i propagandowej kobiet Społeczno-Obywatelskiej Ligi Kobiet w świetle dokumentów Polskiej Partii Robotniczej. Autorka zaprezentowała ich zaangażowanie w przygotowania do referendum 1946 r. oraz wyborów do Sejmu Ustawodawczego w 1947 r. Ponadto zarysowała współpracę SOLK $z$ innymi organizacjami społecznymi oraz jej uczestnictwo w akcjach społecznych i szkoleniach prowadzonych w województwie białostockim.

Ligą Kobiet w województwie białostockim zainteresowała się także Emilia Świętochowska, która nakreśliła rozwój organizacji od momentu powołania w 1945 r. do upadku PRL. W swych artykułach szczególna uwagę zwróciła na położenie społeczne i zawodowe kobiet oraz sposoby wykorzystywania sytuacji kobiet przez władze komunistyczne do realizacji celów propagandowych. Według jej ustaleń początkowy okres rozwoju Ligi nie budził większego zainteresowania wśród kobiet, zwłaszcza

s. 28-46; Eadem, Koła Rodzin Milicyjnych - zadania i zakres działań (1969-1989), „Czasopismo Naukowe Instytutu Studiów Kobiecych” 2017, nr 2 (3), s. 74-90; Eadem, Rola kobiety $w$ Polsce Ludowej $w$ świetle treści propagandowych rozpowszechnianych przez Lige Kobiet w latach 1946-1956, „Dzieje Najnowsze” 2018, nr 2, s. 149-179.

27 A. Stasiewicz, op. cit., s. 54.

28 I. Ratman-Liwerska, Stowarzyszenie jako czynnik społeczno-wychowawczej aktywizacji kobiet (na przykładzie badań na Białostocczyźnie), Białystok 1984.

29 Ibidem, s. 123.

30 A. Stasiewicz, op. cit., s. 51-76. 
wiejskich ${ }^{31}$. Podczas realizacji planu 6-letniego kobietę kreowano jako przodowniczke pracy ${ }^{32}$, warunki pracy oraz pomoc kobietom w okręgu białostockim dalekie były jednak od propagowanych w prasie. Szkolenia i kursy w typowo męskich zawodach nie cieszyły się dużym zainteresowaniem i nie dawały kobietom satysfakcjonującej pracy ${ }^{33}$. Po zakończeniu planu 6-letniego nastapiła zmiana polityki wobec kobiet ${ }^{34}$. W artykule pt. Sytuacja społeczna kobiet $w P R L^{35}$ autorka przedstawiła zmieniony kierunek działalności organizacji po 1957 r. do form akceptowanych przez ogół społeczeństwa, tj. pomoc kobietom w przezwyciężaniu problemów zawodowych i prywatnych. Zasygnalizowała jedynie kierunki aktywności organizacji oraz rozwój kół blokowych i kół gospodyń wiejskich ${ }^{36}$. Badajac sytuację społeczno-zawodowa kobiet lat 80. XX w., bardzo ogólnie nakreśliła kierunki działalności podejmowane przez Ligę Kobiet w kraju i województwie białostockim. Organizacja po 1980 r. na nowo próbowała zająć znacząca pozycję wśród kobiet w zakładach pracy. Od 1981 r. funkcjonowała jako Liga Kobiet Polskich, co miało podkreślać powszechność organizacji. Mimo uznania, że błędem była nieobecność działaczek podczas strajku na Wybrzeżu i w Łodzi, to głównym celem działalności było ksztaltowanie opinii społecznej $i$ dezaprobaty wszelkich destrukcyjnych działań podważajacych zasady ustrojowe i praworzadnośc ${ }^{37}$. Swiętochowska zwróciła uwagę, że w 1983 r. podpisano porozumienie o współ-

\footnotetext{
${ }^{31}$ E. Świętochowska-Bobowik, „Kwestia kobieca” i jej propagandowe wykorzystanie przez władze na przykładzie działalności Ligi Kobiet i Wydziału Kobiecego KW PZPR w Białymstoku w latach 1945-1953 [w:] Kobiety a patriotyzm. Konteksty historyczno-pedagogiczne XX-XXI wieku, red. E.J. Kryńska, A. Szarkowska, U. Wróblewska, Białystok 2012, s. $177-184$.

32 M. Dzienis, Przyczynek do badania wizerunku kobiety - robotnicy przodowniczki pracy $w$ prasie $w$ okresie realizacji planu 6-letniego [w:] Współzawodnictwo pracy $w$ życiu gospodarczym $i$ społeczno-politycznym i propagandzie PRL, red. B. Tracz, Katowice 2008, s. 221-229.

33 „W 1952 r. w całym województwie były zaledwie trzy kobiety brygadzistki traktorowe, a na szkolenie zawodowe w tym zakresie zgłosiła się tylko jedna kobieta. W powiecie Bielsk Podlaski kobieta, która ukończyła kurs traktorzystek, pracowała w restauracji i posada ta odpowiadała jej zdecydowanie bardziej niż prace w polu" (E. Świętochowska-Bobowik, op. cit., s. 183; zob. też: Ibidem, s. 182-184).

${ }_{34}$ M. Hajdo, Wizerunek kobiety jako matki, pracownika i działaczki społecznej prezentowany na łamach prasy kobiecej w latach 1948-1956, „Dzieje Najnowsze” 2006, nr 3, s. 66.

35 E. Świętochowska, Sytuacja społeczna kobiet w PRL w latach 1956-1970 na przykładzie województwa białostockiego [w:] „Mała stabilizacja” w województwie białostockim 1956-1970, red. M. Markiewicz, Białystok 2012, s. 197-210.

36 Ibidem, s. 202-210.

37 Cyt. za: E. Świętochowska, Sytuacja społeczno-zawodowa kobiet w ostatniej dekadzie PRL [w:] Kobiety „na zakręcie”..., s. 302.
} 
pracy między Zarządem Głównym Ligi Kobiet a Radą Główną Kół Gospodyń Wiejskich i Krajowym Wydziałem Spółdzielczyń, tworząc Polski Komitet Współdziałania Organizacji i Środowisk Kobiecych. Informacje o wojewódzkiej LK kończą się na połowie lat 80., kiedy to w województwie funkcjonowały 183 koła zrzeszajace 6774 członkin ${ }^{38}$. Mimo prób powrotu do niesienia realnej pomocy kobietom w życiu zawodowym i prywatnym podejmowanych przez zarząd główny ciagle szerzono propagandę ideologiczną wśród kobiet ${ }^{39}$.

Największą uwagę na działalność Ligi Kobiet w województwie białostockim zwróciła Małgorzata Dajnowicz. Przedstawiła działalność organizacji prezentowaną na łamach „Naszej Pracy” (1947-1953), „Kobiety Dzisiejszej” (1946-1947), „Kobiety” (1947-1949) oraz „Zwierciadła” (1957-1961; 1982-1989). W głównej mierze informacje zawarte w tych artykułach dotyczą działalności Ligi na terytorium całego kraju, pojawiają się też jednak wiadomości odnoszące się bezpośrednio do województwa białostockiego.

W artykule pt. Działalność Społeczno-Obywatelskiej Ligi Kobiet $w$ świetle „Naszej Pracy” (1947-1949) przedstawiła zarys historyczny powołania organizacji oraz wskazała główne kierunki działalności, opierając się głównie na źródłach archiwalnych z AAN oraz prasowych. Nakreśliła strukturę organizacji, a także aktywności społeczne i polityczne podejmowane na terenie kraju. Odnosząc się do województwa białostockiego, odnotowała organizowanie kursów kroju i mody przy współpracy z kuratorium oświaty, utworzenie Komisji Społeczno-Obyczajowej oraz przeprowadzenie w 1948 r. wyborów do Zarządu Wojewódzkiego LK, bez przedstawienia ich wyników. Analizując „Naszą Pracę”, zwróciła też uwagę na szerzona na łamach pisma propagandę konieczności „walki o pokój”41. Program ideowo-wychowawczy Ligi obejmował nie tylko pomoc kobietom i dzieciom, lecz także ich zaangażowanie w sferze politycznej i propagandowej. Liga Kobiet angażowała się w prace Światowej Demokratycznej Federacji Kobiet, a na łamach pisma nawoływała do pomocy w odbudowie zniszczonej wojną Polski i pomocy kobietom $z$ krajów dotkniętych działa-

\footnotetext{
38 Ibidem, s. 301-302.

39 E. Świętochowska, Sytuacja społeczna kobiet..., op. cit., s. 204.

40 M. Dajnowicz, Działalność Społeczno-Obywatelskiej Ligi Kobiet w świetle „Naszej Pracy” (1947-1949) [w:] Polityka i politycy w prasie XX i XXI wieku..., s. 295-307.

41 Eadem, "Walka o pokój” w wypowiedziach propagandowych publikowanych na łamach „Naszej Pracy” - biuletynie Ligi Kobiet (1947-1953) [w:] Bezpieczeństwo Europy - bezpieczeństwo Polski, t. 5, red. E. Maj, W. Sokół, A. Szwed-Walczak, Ł. Jędrzejski, Lublin 2017, s. $409-420$.
} 
niami wojennymi. W artykule brak jednak odniesień do działalności białostockiego oddziału Ligi Kobiet w tym zakresie. Badania na temat działań przedstawicielek tej organizacji w województwie białostockim w świetle „Naszej Pracy” prowadziła też autorka niniejszego artykułu ${ }^{42}$.

Małgorzata Dajnowicz dużo uwagi poświęciła również działaniom podejmowanym na Białostocczyźnie w 1975 r. w czasie obchodów Międzynarodowego Roku Kobiet oraz 30-lecia istnienia Ligi Kobiet ${ }^{43}$. Zarysowała kierunki działalności oraz przemiany programowo-ideowe organizacji zachodzace pod wpływem przemian politycznych. Jak zaznaczyła: Międzynarodowy Rok Kobiet miał być okazja do akcentowania wkładu kobiet $w$ rozwój Polski Ludowej" ${ }^{44}$. Autorka wskazała aktywności podejmowane przez członkinie, wynikające $z$ rezolucji Zgromadzenia Ogólnego ONZ oraz uchwały rządu PRL. Głównym celem obchodów na Białostocczyźnie było propagowanie zasług białostockich kobiet w wyzwolenie miasta oraz sylwetek przodujacych kobiet $z$ regionu. Ponadto upowszechnianie dokonań i kierunków rozwoju organizacji w województwie miało na celu nie tylko poszerzenie składu osobowego członkiń, lecz przede wszystkim uświadomienie kobietom konieczności istnienia i zasług Ligi w poprawie warunków ich życia codziennego.

Kolejny artykuł Małgorzaty Dajnowicz prezentuje aktywność Ligi Kobiet (od 1982 r. Ligi Kobiet Polskich) na łamach „Zwierciadła”45. Autorka nakreśliła kierunki działalności Ligi w dobie PRL oraz cechy periodyku. Według jej ustaleń tygodnik nie cieszył się popularnością w województwie białostockim. Sprzedawano tylko 1-2\% nakładu ${ }^{46}$. Działalność Ligi prezentowana na łamach pisma dotyczyła m.in. zatrudnienia kobiet, prowadzenia gospodarstwa domowego oraz wyborów do rad narodowych. W latach 80. w specjalnej rubryce pisma pt. LKP $w$ działaniu prezentowano aktywność organizacji w terenie, w tym w województwie białostockim ${ }^{47}$.

\footnotetext{
${ }^{42}$ Zob. A. Drozdowska, O działalności Ligi Kobiet $w$ okregu białostockim ( $w$ świetle „Naszej Pracy") [w:] Polityka i politycy $w$ prasie XX $i$ XXI wieku. Polityka $w$ prasie kobiecej, red. M. Dajnowicz, A. Miodowski, Białystok 2018 [w druku].

43 M. Dajnowicz, Obchody Międzynarodowego Roku Kobiet 1975 na Białostocczyźnie (na tle głównych kierunków działalności Ligi Kobiet w kraju i regionie), „Czasopismo Naukowe Instytutu Studiów Kobiecych” 2017, nr 1 (2), s. 9-25.

44 Ibidem, s. 22.

45 M. Dajnowicz, „Zwierciadło” - platforma polityczna..., s. 67-89.

46 Ibidem, s. 73.

47 Ibidem, s. 81
} 
Kontynuacja badań nad treścia „Zwierciadła”48 pozwoliła autorce wskazać aktywność polityczną organizacji prezentowana na łamach pisma w ostatniej dekadzie PRL.

Wśród przeanalizowanych przez badaczkę pism znajduje się także dwutygodnik Społeczno-Obywatelskiej Ligi Kobiet „Kobieta Dzisiejsza”49. Artykuł prócz rysu historycznego organizacji i charakterystyki pisma zawiera analizę treści publikowanych prac traktujących o kierunkach aktywności organizacji. Autorce udało się też wskazać działania podejmowane wówczas w województwie białostockim i promowane na łamach pisma $^{50} . Z$ jej ustaleń wynika, że zarząd Ligi Kobiet w województwie białostockim w pierwszym okresie rozwoju organizacji na tle innych województw nie przodował w realizacji założeń Zarządu Głównego Ligi Kobiet ${ }^{51}$.

W ostatnim czasie ukazała się także rozszerzona analiza „Kobiety Dzisiejszej”, która od 1947 r. ukazywała się pt. „Kobieta”52. Artykuł, który ukazał się w bieżącym roku, prezentuje przyjęte przez SOLK role potwierdzające jej przydatność w rozwiazywaniu problemów kobiet, a tym samym konieczność jej istnienia. Zarysowując struktury organizacji, Małgorzata Dajnowicz nakreśliła też krótkie noty biograficzne członkiń zarządu głównego. Oba pisma prezentowały główne obszary aktywności SOLK, niewiele jednak było w nim informacji na temat działalności w województwie białostockim. Autorka wspomniała o przeprowadzonych w 1948 r. wyborach do Zarządu Wojewódzkiego LK oraz publikacji treści o aktywności organizacji w Białymstoku, których celem było zachęcenie czytelniczek do angażowania się w działalność Ligi na swoim obszarze. Nie wskazano jednak, na czym polegała aktywność na Białostocczyźnie. W artykule za-

\footnotetext{
48 M. Dajnowicz, Kobiety - polityka - wybory w świetle „Zwierciadła: Pisma Ligi Kobiet Polskich" (1982-1990) [w:] Rzeczpospolita w koncepcjach polskich partii i środowisk politycznych XX i XXI wieku, red. G. Radomski, M. Strzelecki, K. Sopolińska, Torun 2018, s. $107-125$.

49 Eadem, „Kobieta Dzisiejsza. Dwutygodnik Społeczno-Obywatelskiej Ligi Kobiet” jako platforma informacyjna o kierunkach prac organizacji ( $w$ poczatkowym okresie formowania struktur) [w:] Polityka i politycy w prasie XX i XXI wieku. Prasa..., s. 73-83.

50 „Liga bierze czynny udział w pracach wojewódzkiego Wydziału Opieki Społecznej, objęła patronat nad oddziałem położniczym miejskiego szpitala, opiekując się matkami i noworodkami, przystępuje do organizacji przedszkoli” (cyt. za: Ibidem, s. 78).

51 Ibidem, s. 79.

52 Eadem, Działalność Ligi Kobiet na obszarze kraju w świetle czasopism organizacji „Kobiety Dzisiejszej” (1946-1947) i „Kobiety” (1947-1949), „Rocznik Historii Prasy Polskiej” 2018, t. 21, z. 3 (51), s. 57-73.
} 
prezentowano najczęściej pojawiające się zagadnienia na łamach analizowanych pism oraz inicjatywy podejmowane przez Ligę w kraju.

Najwięcej uwagi działalności Ligi Kobiet w województwie białostockim Małgorzata Dajnowicz poświęciła w artykułach pt. Liga Kobiet $w$ terenie oraz Główne kierunki działalności Ligi Kobiet w Polsce do 1975 rok $u^{53}$. Zawarła w nich informacje na temat utworzenia organizacji w Białymstoku, liczebności jej składu oraz kierunków działalności podejmowanych w poszczególnych dekadach PRL, do 1981 r. Autorka ukazała zmiany zachodzace $\mathrm{w}$ polityce promowanej przez władze komunistyczne, które również wyznaczały kierunki aktywności organizacji kobiecej. Działania podejmowane w województwie białostockim koncentrowały się głównie na niesieniu realnej pomocy kobietom w ich miejscu zamieszkania poprzez m.in. tworzenie poradni prawno-społecznych. Konieczność opuszczenia przez Ligę zakładów pracy wzmogła jej aktywność osiedlowa. Ciagle podejmowano starania propagandowe mające na celu aktywizacje coraz większej liczby kobiet. Autorka wskazywała, że jednym z najaktywniejszych kół w województwie był oddział w Łomży. W artykule pt. Liga Kobiet $w$ terenie badaczka zarysowała przyczyny przyjęcia nowej nazwy organizacji (Liga Kobiet Polskich) oraz kierunki wyznaczone w listopadzie 1981 r. podczas VIII Nadzwyczajnego Krajowego Zjazdu Ligi Kobiet.

Wszystkie przywołane wyżej prace stanowia jedynie przyczynek do dalszych badań nad tym tematem. Jak wykazano wyżej, działalność najbardziej masowej organizacji kobiecej wymaga przeprowadzenia szczegółowych badań. Należy przeanalizować prasę kobieca pod względem działalności Ligi Kobiet w województwie białostockim w okresie trwania Polski Ludowej. Przyszłe badania powinny się koncentrować na odzwierciedleniu dziejów organizacji w świetle przemian politycznych w kraju. Priorytetem jest opracowanie struktur i działań terenowych. Należy porównać informacje zawarte $\mathrm{w}$ materiałach archiwalnych i prasowych z rzeczywistym postrzeganiem działalności Ligi przez członkinie i osoby niezrzeszone w organizacji. Tematyka poruszana przez członkinie kół na

${ }^{53}$ Eadem, Liga Kobiet $w$ terenie. Kierunki działalności organizacji na przykładzie struktur białostockich w latach 1966-1981, „Niepodległość i Pamięć” 2018, nr 2 (62), s. 161-178; Eadem, Główne kierunki działalności Ligi Kobiet w Polsce Ludowej do 1975 roku (ze szczególnym uwzględnieniem województwa białostockiego), „Zeszyty Naukowe Uniwersytetu Jagiellońskiego. Prace Historyczne” 2018, z. 3, s. 579-601. 
spotkaniach pozwoli wskazać podporządkowanie poszczególnych oddziałów wytycznym Zarządu Głównego LK. W jakim stopniu Liga w terenie spełniała oczekiwania władzy, a w jakim zwykłych kobiet, odbiorczyń ich działań? Podmiotem zainteresowania należy uczynić odwzorowanie realnego zasięgu oddziaływania organizacji na społeczeństwo. Przyszłe całościowe opracowanie działalności organizacji winno wskazać najbardziej aktywne regiony okręgu białostockiego na tle innych województw Polski Ludowej.

\section{Bibliografia}

\section{Opracowania}

Ćwik Urszula, Podstawowe założenia Społeczno-Obywatelskiej Ligi Kobiet $w$ świetle „Mody i Życia Praktycznego” (1946-1951) [w:] Polityka i politycy $w$ prasie XX i XXI wieku. Prasa organizacji politycznych, red. Małgorzata Dajnowicz, Adam Miodowski, Białystok : Wydawnictwo Humanica, 2017, s. $49-58$.

Dajnowicz Małgorzata, Działalność Ligi Kobiet na obszarze kraju w świetle czasopism organizacji - „Kobiety Dzisiejszej” (1946-1947) $i$ „Kobiety” (1947-1949), „Rocznik Historii Prasy Polskiej” 2018, t. 21, z. 3 (51), s. 57-73, ISSN 1509-1074.

Dajnowicz Małgorzata, Działalność Społeczno-Obywatelskiej Ligi Kobiet w świetle „Naszej Pracy” (1947-1949) [w:] Polityka i politycy w prasie XX i XXI wieku, red. Małgorzata Dajnowicz, Adam Miodowski, Białystok : Wydawnictwo Humanica, 2016, s. 295-307.

Dajnowicz Małgorzata, Główne kierunki działalności Ligi Kobiet w Polsce Ludowej do 1975 roku (ze szczególnym uwzględnieniem województwa białostockiego), „Zeszyty Naukowe Uniwersytetu Jagiellońskiego. Prace Historyczne" 2018, z. 3, s. 579-601, ISSN 0083-4351.

Dajnowicz Małgorzata, „Kobieta Dzisiejsza. Dwutygodnik Społeczno-Obywatelskiej Ligi Kobiet" jako platforma informacyjna o kierunkach prac organizacji (w poczatkowym okresie formowania struktur) [w:] Polityka i politycy w prasie XX i XXI wieku. Prasa organizacji politycznych, red. Małgorzata Dajnowicz, Adam Miodowski, Białystok : Wydawnictwo Humanica, 2017, s. 73-83. 
Dajnowicz Małgorzata, Kobiety - polityka - wybory w świetle „Zwierciadła: Pisma Ligi Kobiet Polskich” (1982-1990) [w:] Rzeczpospolita w koncepcjach polskich partii $i$ środowisk politycznych XX $i$ XXI wieku, red. Grzegorz Radomski, Michał Strzelecki, Katarzyna Sopolińska, Torun : Wydawnictwo Naukowe Uniwersytetu Mikołaja Kopernika, 2018, s. 107-125.

Dajnowicz Małgorzata, Liga Kobiet w terenie. Kierunki działalności organizacji na przykładzie struktur białostockich w latach 1966-1981, „Niepodległość i Pamięć” 2018, nr 2 (62), s. 161-178, ISSN 1427-1443.

Dajnowicz Małgorzata, Obchody Międzynarodowego Roku Kobiet 1975 na Białostocczyźnie (na tle głównych kierunków działalności Ligi Kobiet $w$ kraju i regionie), „Czasopismo Naukowe Instytutu Studiów Kobiecych” 2017, nr 1 (2), s. 9-25, ISSN 2451-3539.

Dajnowicz Małgorzata, „Walka o pokój” $w$ wypowiedziach propagandowych publikowanych na łamach „Naszej Pracy” - biuletynie Ligi Kobiet (19471953) [w:] Bezpieczeństwo Europy - bezpieczeństwo Polski, t. 5, red. Ewa Maj, Wojciech Sokól, Anna Szwed-Walczak, Łukasz Jędrzejski, Lublin : Wydawnictwo UMCS, 2017, s. 409-420.

Dajnowicz Małgorzata, „Zwierciadło” - platforma polityczna Ligi Kobiet w okresie PRL (1957-1961, 1982-1989), „Rocznik Historii Prasy Polskiej” 2017, t. 20, z. 3 (47), s. 67-90, ISSN 1509-1074.

Drozdowska Agnieszka, O działalności Ligi Kobiet $w$ okręgu białostockim (w świetle „Naszej Pracy”) [w:] Polityka i politycy w prasie XX i XXI wieku. Polityka w prasie kobiecej, red. Małgorzta Dajnowicz, Adam Miodowski, Białystok : Wydawnictwo Humanica, 2018 [w druku].

Dzienis Magdalena, Przyczynek do badania wizerunku kobiety - robotnicy przodowniczki pracy $w$ prasie $w$ okresie realizacji Planu 6-letniego [w:] Współzawodnictwo pracy $w$ życiu gospodarczym i społeczno-politycznym i propagandzie PRL, red. Bogusław Tracz, Katowice : IPN, 2008, s. 221-229.

Fidelis Małgorzata, Kobiety, komunizm i industrializacja w powojennej Polsce, przeł. Maria Jaszczurowska, Warszawa : Wydawnictwo W.A.B. - Grupa Wydawnicza Foksal, 2015, ISBN 978-83-7629-764-4.

Hajdo Małgorzata, Wizerunek kobiety jako matki, pracownika i działaczki społecznej prezentowany na łamach prasy kobiecej w latach 1948-1956, „Dzieje Najnowsze” 2006, nr 3, s. 55-72, ISSN 0419-8824. 
Jarosz Dariusz, Idee, programy i realia: funkcje Ligi Kobiet w porzadku instytucjonalnym Polski Ludowej (1945-1957) [w:] Działaczki społeczne, feministki, obywatelki. Samoorganizowanie się kobiet na ziemiach polskich po 1918 roku (na tle porównawczym), t. 2, red. Agnieszka Janiak-Jasińska, Katarzyna Sierakowska, Andrzej Szwarc, Warszawa : Wydawnictwo Neriton, 2009, s. 307-330.

Jarosz Dariusz, Kwestia kobieca w Polsce stalinowskiej [w:] Dariusz, Jarosz, Polacy a stalinizm 1948-1956, Warszawa : Instytut Historii PAN, 2000. Jarosz Dariusz, Wzory osobowe i modele awansu społecznego kobiety wiejskiej $w$ Polsce w prasie periodycznej z lat 1949-1955 [w:] Kobieta i edukacja na ziemiach polskich w XIX i XX wieku, red. Anna Żarnowska, Andrzej Szwarc, Warszawa : DiG, 1993, s. 253-266.

Jarska Natalia, A Patriarchal Marriage? The Women's Movement and The Communist Party in Poland (1945-1989), „Kwartalnik Historyczny” 2018, Vol. CXXV, Eng.-Language Edition no. 2, pp. 7-37, PL ISSN 0023-5903. Jarska Natalia, Kobiety z marmuru. Robotnice w Polsce w latach 1945-1960, Warszawa : IPN, 2015, ISBN 978-83-7629-764-4.

Jarska Natalia, Liga Kobiet $w$ terenie. Działalność Zarzadu Dzielnicowego Poznań-Wilda w latach 1956-1966 [w:] Letnia Szkoła Historii Najnowszej 2009. Referaty, t. 3, red. Łukasz Kamiński, Tomasz Kozłowski, Warszawa : IPN, 2010, ISBN 978-83-7629-167-3.

Jarska Natalia, Obchody Dnia Kobiet w Polsce Ludowej, „Dzieje Najnowsze” 2010, nr 4, s. 15-28, ISSN 0419-8824.

Jurkowska Katarzyna, Kłopoty z tożsamościa, czyli Liga Kobiet Polskich, „Ośka” 2000, nr 2 (11), s. 37-38, ISSN 1429-7027.

Madejska Marta, Aleja włókniarek, Wołowiec : Wydawnictwo Czarne, 2018, ISBN 978-83-8049-708-5.

Marcinkiewicz-Kaczmarczyk Anna, Koła Rodzin Milicyjnych - powstanie, organizacja i praca propagandowa, „Czasopismo Naukowe Instytutu Studiów Kobiecych” 2017, nr 1 (2), s. 74-90, ISSN 2451-3539.

Marcinkiewicz-Kaczmarczyk Anna, Koła Rodzin Milicyjnych - zadania i zakres działań (1969-1989), „Czasopismo Naukowe Instytutu Studiów Kobiecych” 2017, nr 2 (3), s. 74-90, ISSN 2451-3539.

Marcinkiewicz-Kaczmarczyk Anna, Rola kobiety w Polsce Ludowej w świetle treści propagandowych rozpowszechnianych przez Lige Kobiet $w$ latach 1946-1956, „Dzieje Najnowsze” 2018, nr 2, s. 149-179, ISSN 0419-8824. 
Marcinkiewicz-Kaczmarczyk Anna, Rola Ligi Kobiet w popularyzowaniu polityki władz „Polski Ludowej” [w:] „Polska Ludowa” 1944-1989-wybrane problemy historii politycznej $i$ społecznej, red. Dorota Litwin-Lewandowska, Krzysztof Bałękowski, Lublin : Wydawnictwo Naukowe Tygiel, 2016, s. 283-301.

Marcinkiewicz-Kaczmarczyk Anna, Treści propagandowe rozpowszechniane przez Społeczno-Obywatelska Lige Kobiet/Lige Kobiet na podstawie pisma „Poznajmy Prawde”" (1946-1952) [w:] Polityka i politycy w prasie XX i XXI wieku. Prasa organizacji politycznych, red. Małgorzata Dajnowicz, Adam Miodowski, Białystok : Wydawnictwo Humanica, 2017, s. 59-72. Mrozik Agnieszka, Wywołać z milczenia. Historia kobiet $w$ PRL-u - kobiety $w$ historii PRL-u, „Teksty Drugie” 2014, nr 4, s. 112-119, ISSN 08670633.

Perkowski Piotr, Aktywność zawodowa gospodyń domowych na łamach prasy kobiecej Polski Ludowej [w:] Koniec mitu niewinności? Płeć $i$ seksualność w socjalizacji i edukacji, red. Lucyna Kopciewicz, Edyta Zierkiewicz, Warszawa : Wydawnictwo ENETEIA, 2009, s. 289-315.

Ratman-Liwerska Izabela, Stowarzyszenie jako czynnik społeczno-wychowawczej aktywizacji kobiet (na przykładzie badań na Białostocczyźnie), Białystok : Dział Wydawnictw Filii Uniwersytetu Warszawskiego, 1984.

Stańczak-Wiślicz Katarzyna, Perkowski Piotr, Dzieje kobiet w PRL - stan i perspektywy badań [w:] Dzieje kobiet w Polsce. Dyskusja wokót przyszłej syntezy, red. Krzysztof A. Makowski, Poznań : Wydawnictwo Nauka i Innowacje, 2014, s. 134-156.

Stasiewicz Agnieszka, Działalność Społeczno-Obywatelskiej Ligi Kobiet w latach 1945-1948 na Białostocczyźnie w świetle dokumentów PPR [w:] Kobiety na zakręcie 1933-1989, red. Ewa Chabros, Agnieszka Klarman, Wrocław : IPN, 2014, s. 52-76.

Świętochowska Emilia, Sytuacja społeczna kobiet w PRL w latach 19561970 na przykładzie województwa białostockiego [w:] „Mała stabilizacja” w województwie białostockim 1956-1970, red. Marcin Markiewicz, Bialystok : IPN, 2012, s. 197-210.

Świętochowska Emilia, Sytuacja społeczno-zawodowa kobiet w ostatniej dekadzie PRL [w:] Kobiety na zakręcie 1933-1989, red. Ewa Chabros, Agnieszka Klarman, Wrocław : IPN, 2014. 
Świętochowska-Bobowik Emilia, „Kwestia kobieca” i jej propagandowe wykorzystanie przez władze na przykładzie działalności Ligi Kobiet $i$ Wydziału Kobiecego KW PZPR w Białymstoku w latach 1945-1953 [w:] Kobiety a patriotyzm. Konteksty historyczno-pedagogiczne XX-XXI wieku, red. Elwira Joanna Kryńska, Agnieszka Szarkowska, Urszula Wróblewska, Białystok : Trans Humana, 2012, s. 177-184.

Zwolski Marcin, Więzienie $w$ Białymstoku $w$ latach 1944-1956, Białystok : IPN, 2011, ISBN 978-83-62357-48-2.

\section{Zasoby internetowe}

Klepacz Apolonia, Liga Kobiet Polskich ma 100 lat, [online], [Dostęp: 17.10.2018]. Dostępny w World Wide Web: <https://goo.gl/cgm7LB>.

Kruszyński Marcin, O zaangażowaniu kobiet $w$ działalność partii komunistycznej i Ligi Kobiet na przykładzie lubelskiego UMCS z czasów stalinowskich, „Komunizm: System - Ludzie - Dokumentacja” 2013, nr 2, [online], [Dostęp: 11.10.2018]. Dostępny w World Wide Web: <http:// bitly.pl/TVzaC>.

Lubik-Reczek Natasza, Reczek Rafał, Liga Kobiet - organizacja „reprezentujaca” interesy kobiet $w$ Polsce Ludowej. Zarys działania, „Środkowoeuropejskie Studia Polityczne" 2013, t. 4, [online], [Dostęp: 12.10.2018]. Dostępny w World Wide Web: <http://bitly.pl/FWePD>.

Nowak Barbara, Serving women and the state: the league of women in Communist Poland, praca dokt., Ohio State University, 2004, [Dostęp: 7.09.2018]. Dostępny w World Wide Web: <http://bitly.pl/y5y0m>.

Nowakowska-Wierzchoś Anna, Społeczno-Obywatelska Liga Kobiet (19451949) i Zwiazek Kobiet Polskich im. Marii Konopnickiej we Francji (19441950) - dokumenty programowe, „Komunizm: System - Ludzie - Dokumentacja” 2013, nr 2, [online], [Dostęp: 10.10.2018]. Dostępny w World Wide Web: <http://bitly.pl/ejwnp>.

Walczewska Sławomira, Liga Kobiet - jedyna organizacja kobieca w PRL, [Dostęp: 30.10.2018]. Dostępny w World Wide Web: <http://bitly.pl/ amOZ3>. 